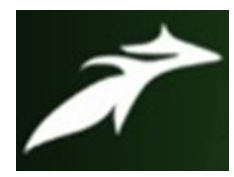

Jainuddin S. M et al, International Journal of Advances in Agricultural Science and Technology,

Vol.8 Issue.1, January-2021, pg. 1-12

ISSN: 2348-1358

Impact Factor: 6.057

NAAS Rating: 3.77

\title{
Instability and Seasonal Production Analysis of Oilseed Crops in India
}

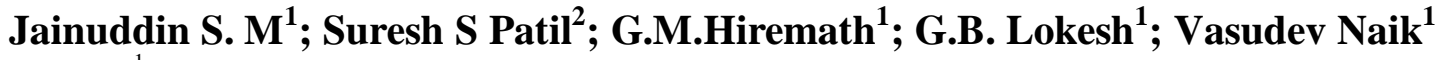 \\ ${ }^{1}$ Assistant Professor, Department of Agricultural Economics, UAS, Raichur-584 104 \\ ${ }^{2}$ Dean (Agri.), College of Agriculture, Kalaburagi-585103 \\ Corresponding Author's Email: smjainu@gmail.com \\ DOI: 10.47856/ijaast.2021.v08i1.001
}

\begin{abstract}
The study was conducted based on secondary data collected for the period covered span of 30 years from 1989-90 to 2018-19. The study includes analysis of all nine oilseed crops. The study concluded that more area, production and productivity of oilseeds were contributed by kharif season crops than compared to rabi season in the country. The variation in yield of oilseeds was mostly observed in kharif crops than compared to rabi crops. The sunflower, safflower, nigerseed and castor seed showed more fluctuation in area, whereas in production of all crops showed mild variation except sesamum and in productivity higher instability was noticed in soyabean, safflower and groundnut crops. As per the suggestions are concerned, only improving productivity of oilseeds is a better option rather than area in our country. Therefore research efforts may be concentrated on evolving and popularization of suitable yield increasing technology such as High Yielding Varieties, Biotic and Abiotic stress resistant varieties, instability in production and productivity was minimized by expansion of area under irrigation and large scale promotion of stabilization measures like crop insurance which can enhance the per unit production as well as stabilize the area and yield of oilseed crops.
\end{abstract}

\section{Introduction}

The oilseeds sector plays an important role in the Indian agriculture next only to food grains in terms of area, production and value. All the nine oilseeds, such as seven edible oilseeds i.e. groundnut, rape-seed mustard, soybean, sunflower, sesame, safflower and Niger, and two non-edible oilseeds, viz. Castor and Linseed is grown in the country due to favourable climatic conditions. Oilseeds cultivation was undertaken in an area 11.10 million hectares contributed around 6.20 million tons of production with yield $520 \mathrm{~kg}$ per hectare during 1950-51 (GOI, 2019). Further, area under oilseeds 18.62 million hectares contributed 11.27 million tons production and yield $605 \mathrm{~kg} / \mathrm{ha}$ during 1986-87 which increased to area 28 million hectares and production 32.74 million tons during 2013-14 (GOI, 2019). The area 


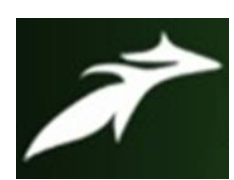

Jainuddin S. M et al, International Journal of Advances in Agricultural Science and Technology,

Vol.8 Issue.1, January-2021, pg. 1-12

ISSN: 2348-1358

Impact Factor: 6.057

NAAS Rating: 3.77

under oilseeds starts decreasing from 2014 onwards. At presently, total area under oilseeds is around 24.79 million hectares which contributed 31.52 million ton production with yield $1271 \mathrm{~kg}$ per hectares during 2018-19 (GOI, 2019).

Edible oil constitutes an important part of our daily diet. Domestic consumption of edible oils has increased substantially over the years and has touched the level of 19.82 million tonnes during 2012-13 (Anon., 2014). The growth in production of domestic edible oils (9.22 million tonnes in 2012-13) has not been able to keep pace with the growth in consumption and the gap between production and consumption is being met through imports. The cost of import of edible oil with a huge drain of the exchequer has touched to approximately Rs 60,000 crores during 2012-13 (Anon., 2014).

Even though India is the largest producer of oilseeds in the world, which is unable to meet the domestic demands of vegetable oils and the Indian government's was spending millions of rupees on programmes and policies of oilseeds such as National Oilseed Development Project (1985), Technology Mission on Oilseeds (1986), Oil Palm Development Programme (1991) under Technology Mission on Oilseeds and Pulses, Integrated Scheme on Oilseeds, Pulses, Oil Palm and Maize (2004), National Mission on Oilseeds and Oil Palm (2014) to meet demand and supply of oilseeds gap and also foster oilseed sectors growth in our country. These policies and programmes main aim is to increase the production of nine oilseed crops are grown in the country out of which seven are edible oilseeds such as groundnut, rapeseed-mustard, soybean, sunflower, sesame, safflower and Niger, and two are of non-edible oilseeds such as castor and linseed

In our country, millions of rupees are spent annually by government on programmes and policies to meet demand and supply of oilseeds gap and also foster oilseed sectors growth in our country. Yet its performance was not impressive, still depends on imports of oilseeds. Hence, it is needed to understand the phenomenon of why production of oilseeds was not achieved to the remarkable level in our country. Hence, this article analysis sources of oilseeds growth and Changing pattern in area production oilseeds in different period such as before ISOPOM and after ISOPOM scheme in India. Analyse the seasonal production and 


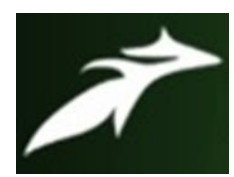

Jainuddin S. M et al, International Journal of Advances in Agricultural Science and Technology,

Vol.8 Issue.1, January-2021, pg. 1-12

ISSN: 2348-1358

Impact Factor: 6.057

NAAS Rating: 3.77

productivity of oilseeds and solutions to the self sufficiency in the edible oils in the future. Analyses the constraints oilseeds production in India

\section{Data and Methodology}

The study was conducted based on secondary data collected for the period covered span of 30 years from 1989-90 to 2018-19 which was further subdivided in to two periods on the basis of policy regimes. Period-I (Pre-ISOPOM) from 1989-90 to 2003-04, it is the period before implementation of Integrated Scheme on Oilseeds, Pulses, Oil Palm and Maize. Period-II (Post-ISOPOM) from 2004-05 to 2018-19, it is the period after implementation of ISOPOM. Time series data was used for the study; the variables for the analysis include area planted, production and productivity of the oilseed crops (both Kharif and Rabi) during the same period. The study includes nine oilseed crops out of which seven are edible oilseeds such as groundnut, rapeseed-mustard, soybean, sunflower, sesamum, safflower and Niger, and two are non-edible oilseeds such as castor and linseed. The data on variables was obtained from various secondary sources like RBI reports, FAOSTAT reports, DES, DAC, District Statistical Office, Indiastat.com, etc.

\section{Growth rate formulae (Damodar N. Gujarati and Sangeetha, 2007)}

The compound annual growth rates (CAGR) analysis was used to estimate the growth in area, production and productivity of oilseeds in India. The CAGR were computed by using the exponential function of the form.

$$
\mathrm{Y}=\mathrm{AB}^{\mathrm{t}}
$$

after substitution of $\log$ to equation

$\log y=\log \mathrm{A}+\mathrm{t} \log \mathrm{B}$

Where, $Y=$ area, production, productivity of oilseeds in the year ' $t$ '

$\mathrm{A}=$ constant

$\mathrm{B}=$ regression coefficient, and

$\mathrm{t}=$ time in years starting from base year 1989-2018.

Compound growth rate $=[$ Antilog B-1 $] \times 100$ 


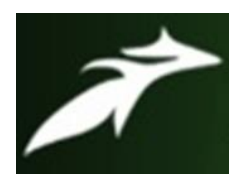

Jainuddin S. M et al, International Journal of Advances in Agricultural Science and Technology,

Vol.8 Issue.1, January-2021, pg. 1-12

ISSN: 2348-1358

Impact Factor: 6.057

NAAS Rating: 3.77

To test the significance of growth rates, correlation coefficients was estimated by the following formula,

$\mathrm{r}=\{\operatorname{Cov} .(\mathrm{Y} . \mathrm{t}) / \sqrt{\operatorname{Var}(t) \cdot(\operatorname{Var} Y)}\}$

Where, $r=$ correlation coefficient,

$\mathrm{Y}=$ area/production/yield, and

$\mathrm{T}=$ time

Coefficient of Variation (CV): Coefficient of Variation (CV) was used to estimate the instability of area, production and productivity of oilseeds (Pandey et al., 2005; Umar et al., 2019; Dastagir and Jainuddin, 2017). CV is standard deviation expressed as a percentage of mean value and is most popular measure which indicates the extent of instability.

It is defined as

$$
C V=\frac{\sigma_{i j}}{\bar{x}_{i j}}
$$

Where, $C V=$ Coefficient of variation

$\sigma_{i j}=$ Standard Deviation of the ith variable in the jth crop

$\bar{x}_{i j}=$ Arithmetic Mean of the ith variable in the jth crop

\section{Result and Discussion}

\section{Growth and Instability of Area, Production and Productivity of oilseeds}

During the period from 1989-90 to 2018-19, the area, production and productivity of oilseeds have increased nearly by 0.29 percent, 2.17 percent and 1.87 percent respectively. Area under oilseeds ranged from 22.80 million hectares (ha) in 1989-90 to 23.66 million ha in 2003-04 during the pre-ISOPOM period with a growth rate of 0.27 per cent only per annum. After 2004-05 onwards, area under oilseeds steadily decreased at the rate of 0.74 percent per annum during post ISOPOM. The production of oilseeds increased to 25.18 million tons (2003-04) from 16.92 million tons (1989-90) with annual growth rate 2.88 percent per annum during pre ISOPOM period due to increase in the area under oilseeds crops because of implementation of Technology Mission on Oilseeds scheme in the country during 1986. During the period 2004-05 to 2018-19, the production of oilseeds increased to 


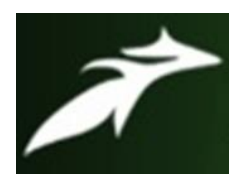

Jainuddin S. M et al, International Journal of Advances in Agricultural Science and Technology,

Vol.8 Issue.1, January-2021, pg. 1-12

ISSN: 2348-1358

Impact Factor: 6.057

NAAS Rating: 3.77

31.52 million tons but with less annual growth (1.86 \%) than compared to period I it may be due to reduction in the area under oilseeds during post ISOPOM period. The oilseeds production was very high variability than compared to area and co-efficient of variations were recorded 13.60 percent during 1989-90 to 2003-04 and 13.93 percent during 2004-05 to 2018-19. The productivity of oilseeds was increased from $742 \mathrm{Kg} / \mathrm{ha}$ to $1271 \mathrm{Kg} / \mathrm{ha}$ with annual growth 1.87 percent during 1989-90 to 2018-19. The annual compound growth rate of productivity of oilseeds in India showed 2.61 percent during 1989-2003 and after launching ISOPOM it increased 2.62 percent per annum.

\section{Seasonal Trends in area, production and productivity of oilseeds}

The area of (Figure 1) oilseeds was shown an increased trend from 22.80 million hectare (1989-90) to 26.19 million hectare (1998-99) may be due to higher area planted during both Kharif and Rabi season. But, from 1999-2000 onwards declining trend was observed in area of oilseeds up to 2002-03. The oilseed area after 2004-05 (Post ISOPOM) onwards showed a mixed trend and the contribution of rabi season area to total oilseeds area was found to be reduced over a period of time may be due to unfavourable climatic conditions. The total oilseeds area drastically reduced during 2002-03 may be due to less rabi area under oilseeds and reduced sowing of oilseed crops during kharif season because of drought and unfavourable weather conditions in the country (Prem Narayan, 2016).

The production of (Figure 2) oilseeds was found to be increased trend from 16.92 million ton in 1989-90 to 24.75 million ton in 1998-99 due increased area under total oilseeds in the country because of Technology Mission on oilseeds (TMO). The production of oilseeds was majorly was contributed by kharif season during 1989-90 to 2018-19 with fluctuations in the productions. The production of oilseeds was drastically reduced during 2002-03 may be due to reduced area under oilseeds because of drought and unfavourable weather conditions in the country (Prem Narayan, 2016). The production of oilseeds was increased to 31.52 million tons during 2018-19 from 25.25 million tons during 2015-16 may be due to technological impact through National Mission on Oilseeds and Oil Palm (2014) scheme in the country. 


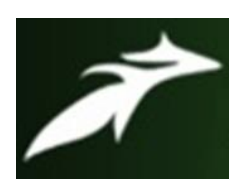

Jainuddin S. M et al, International Journal of Advances in Agricultural Science and Technology,

Vol.8 Issue.1, January-2021, pg. 1-12

ISSN: 2348-1358

Impact Factor: 6.057

NAAS Rating: 3.77

The productivity of (Figure 3) oilseeds showed an increased trend from $742 \mathrm{~kg} / \mathrm{ha}$ during $1989-90$ to $1064 \mathrm{~kg} / \mathrm{ha} 2003-04$ with variability 11.32 percent (Table 1) might be due to technological impact of government programmes such as TMO (1986). Further from 200405 onwards productivity of oilseeds increased drastically with variability 14.80 percent. The variation in yield was mostly observed in kharif crops than compared to rabi crops. The study concluded that more area, production and productivity of oilseeds were contributed by kharif season crops than compared to rabi season in the country.

\section{Growth, instability and production pattern of Nine oilseed crops}

The growth and instability pattern of nine oilseed crops of area, production and yield was computed and presented in the Table 2. Among the nine oilseed crops, soybean was only crop recorded positive annual compound growth rate 1.05 percent in area during 2010-11 to 2019-20. The compound annual growth rate showed that the highest area under sunflower crop was decreased (15.57\% per annum) followed by safflower (14.43\%), Nigerseed $(7.31 \%$ per annum), sesamum (3.87\% per annum), groundnut $(2.55 \%$ per annum), rapeseed and mustard (2.03\% per annum), linseed and castor seed. The castor non edible oil crop reported highest growth rate in production $(3.56 \%$ per annum) followed by groundnut $(2.25 \%$ per annum) and rapeseed-mustard (1.21\% per annum). The decelerated growth rate in production was noticed in safflower (16.37\% per annum) followed by sunflower (11.49\% per annum), nigerseed $(9.96 \%$ per annum), linseed $(3.27 \%$ per annum), sesamum and soyabean. The accelerated growth rate in productivity was noticed in all oilseed crops such as groundnut (4.29\%) followed by linseed (3.89\%), castor seed $(3.12 \%)$, rapeseed-mustard $(2.51 \%)$, sunflower $(1.57 \%)$, safflower and nigerseed. The decelerated growth rate in productivity was noticed in soyabean only during 2010-11 to 2019-20. The highest variation in area was noticed in sunflower, safflower, nigerseed and castor seed, whereas in production all crops showed mild variation except sesamum crop and in productivity highest variation was seen in soyabean, safflower and groundnut.

Among the nine oilseeds crops, the highest area to the total area of oilseeds (Figure 4) was contributed from soyabean followed by groundnut, rapeseed-mustard and sesamum crops during 2010-11 to 2017-18. The highest production to the total production of oilseeds (Figure 


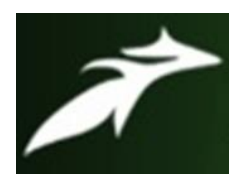

Jainuddin S. M et al, International Journal of Advances in Agricultural Science and Technology,

Vol.8 Issue.1, January-2021, pg. 1-12

ISSN: 2348-1358

Impact Factor: 6.057

NAAS Rating: 3.77

5) was contributed from soyabean, groundnut, rapeseed-mustard and castor seed during 201011 to2019-20. The soyabean contributed (Figure 6) around 39 percent of oilseeds production and 41 percent for area followed by rapeseed-mustard $(25.20 \%$ for production and $23.47 \%$ for area) and groundnut (25.58 \% for production and $19.44 \%$ for area).

\section{Conclusion and Suggestions}

The oilseeds sector plays an important role in the Indian agriculture next only to food grains in terms of area, production and value. Now, total area under oilseeds is around 24.79 million hectares which contributed 31.52 million ton production with yield $1271 \mathrm{~kg}$ per hectares during 2018-19 (GOI, 2019). The study includes all nine oilseed crops. The contribution to total oilseed production was more from of kharif season oilseed crops than rabi season. The study indicated that the higher area and productivity of oilseeds was noticed in kharif season with mild variation than compared to rabi season in the country. The sunflower, safflower, nigerseed and castor seed showed more instability in area, whereas mild instability was noticed in production of all oilseed crops except sesamu. The productivity of soyabean, safflower and groundnut showed more instability than compared to other oilseed crops in the state.

As per the suggestions are concerned, only improving productivity of oilseeds is a better option rather than area in our country. Therefore research efforts may be concentrated on evolving suitable yield increasing technology such as High Yielding Varieties, Biotic and Abiotic stress resistant varieties, instability in production and productivity was minimized by expansion of area under irrigation and large scale promotion of stabilization measures like crop insurance which can enhance the per unit production as well as stabilize the area and yield of oilseed crops. The government agenises like State Agricultural Universities; State Department of Agriculture, Extension units etc., have to arrange for the buyback of oilseeds with processors that could benefit the oilseeds farmers and in turn farmers will expand the area under oilseeds crops which leads to increase in production and productivity of oilseeds in the country. 


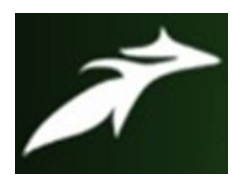

Jainuddin S. M et al, International Journal of Advances in Agricultural Science and Technology,

Vol.8 Issue.1, January-2021, pg. 1-12

ISSN: 2348-1358

Impact Factor: 6.057

NAAS Rating: 3.77

\section{References}

[1]. Damodar, N. G. and Sangeetha (2007), 'Basic Econometrics', Tata McGraw Hill Publishing Company Ltd, New Delhi. 2007, pp: 182-183.

[2]. Dastagir, M.B. and Jainuddin, S.M., 2017, International Trading Prices of India's oilseed Crops: Growth Rates, Elasticities and Foreign Trade Policy, European Scientific Journal, 13(31):185-201. ISSN: 1857 - 7881 (Print) e - ISSN 1857- 7431.

[3]. Government of India. 2019. Department of Agriculture and Co-operation. Ministry of Agriculture and Farmers Welfare. Data accessed from Indiastat.com on 07/10/2020.

[4]. Pandey, L. M., Sant Kumar and Mruthyunjaya. 2005. Instability, supply response and insurance in oilseeds production in India. Agricultural Economics Research Review. 18 (Conference Issue):103-114.

[5]. Prem Narayan, 2016, Recent demand-supply and growth of oilseeds and edible oil in india: an analytical approach, International Journal of Advanced Engineering Research and Science (IJAERS),4(1):32-46.

[6]. Umar S.M, Suhasini K, Jainuddin S.M and Makama S.A, 2019, Sources of growth and instability in cassava production in Nigeria: An evidence from Hazell's Decomposition Model, SKUAST Journal of Research, 21(1): 86-95.

Table 1 Growth and instability of area, production and productivity of Oilseeds in India

\begin{tabular}{|c|c|c|c|c|}
\hline Periods & Year & Area (000 ha) & Production (000 ton) & Yield (Kg/ha) \\
\hline \multirow{4}{*}{ Period I } & $1989-90$ & 22800 & 16924 & 742 \\
\hline & 2003-04 & 23663 & 25186 & 1064 \\
\hline & CAGR $(\%)$ & 0.27 & 2.88 & 2.61 \\
\hline & $\mathrm{CV}(\%)$ & 6.75 & 13.60 & 11.32 \\
\hline \multirow{4}{*}{ Period II } & 2004-05 & 27523 & 24354 & 885 \\
\hline & 2018-19 & 24794 & 31522 & 1271 \\
\hline & CAGR $(\%)$ & -0.74 & 1.86 & 2.62 \\
\hline & $\mathrm{CV}(\%)$ & 4.15 & 13.93 & 14.80 \\
\hline \multirow{4}{*}{ Overall } & $1989-90$ & 22800 & 16924 & 742 \\
\hline & 2018-19 & 24794 & 31522 & 1271 \\
\hline & CAGR $(\%)$ & 0.29 & 2.17 & 1.87 \\
\hline & $\mathrm{CV}(\%)$ & 6.48 & 20.55 & 17.71 \\
\hline
\end{tabular}

Note: Period -I is 1989-90 to 2003-04, Period-II is 2004-05 to 2018-19, Overall is 1989 to 2018

Data Source: MoAFW, Govt. of India, 2020, Data accessed from Indiastat.com on 07/10/2020 


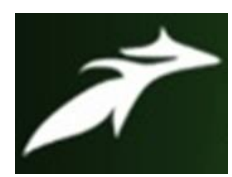

Jainuddin S. M et al, International Journal of Advances in Agricultural Science and Technology,

Vol.8 Issue.1, January-2021, pg. 1-12

ISSN: 2348-1358

Impact Factor: 6.057

NAAS Rating: 3.77

Table 2 Growth and Instability pattern of Nine oilseed crops (2010-11 to 2019-20)

\begin{tabular}{|l|r|r|r|r|r|r|}
\hline \multirow{2}{*}{ Crop } & \multicolumn{2}{|c|}{ Area } & \multicolumn{2}{c|}{ Production } & \multicolumn{2}{c|}{ Yield } \\
\cline { 2 - 7 } & CAGR & \multicolumn{1}{l|}{ CV } & CAGR & CV & CAGR & CV \\
\hline Groundnut & -2.55 & 8.64 & 2.25 & 20.33 & 4.29 & 18.63 \\
\hline Casterseed & -0.93 & 21.26 & 3.56 & 18.52 & 3.12 & 7.04 \\
\hline Linseed & -1.37 & 9.76 & -3.27 & 12.79 & 3.89 & 9.95 \\
\hline Nigerseed & -7.31 & 20.19 & -9.96 & 17.98 & 1.46 & 7.47 \\
\hline Rapeseed and Mustard & -2.03 & 6.81 & 1.21 & 10.44 & 2.51 & 8.63 \\
\hline Safflower & -14.43 & 32.67 & -16.37 & 41.81 & 1.25 & 14.37 \\
\hline Sesamum & -3.87 & 9.56 & -1.92 & 9.24 & 1.56 & 5.85 \\
\hline Soyabean & 1.05 & 6.82 & -1.40 & 15.67 & -3.18 & 18.64 \\
\hline Sunflower & -15.57 & 36.12 & -11.49 & 40.23 & 1.57 & 8.09 \\
\hline Total Oilseed & -1.49 & 3.99 & 0.32 & 8.44 & 1.06 & 8.16 \\
\hline
\end{tabular}

Data Source: MoAFW, Govt. of India, 2020, Data accessed from Indiastat.com on 07/10/2020

Note: Area and yield data up to 2017-18 and production data up to 2019-20

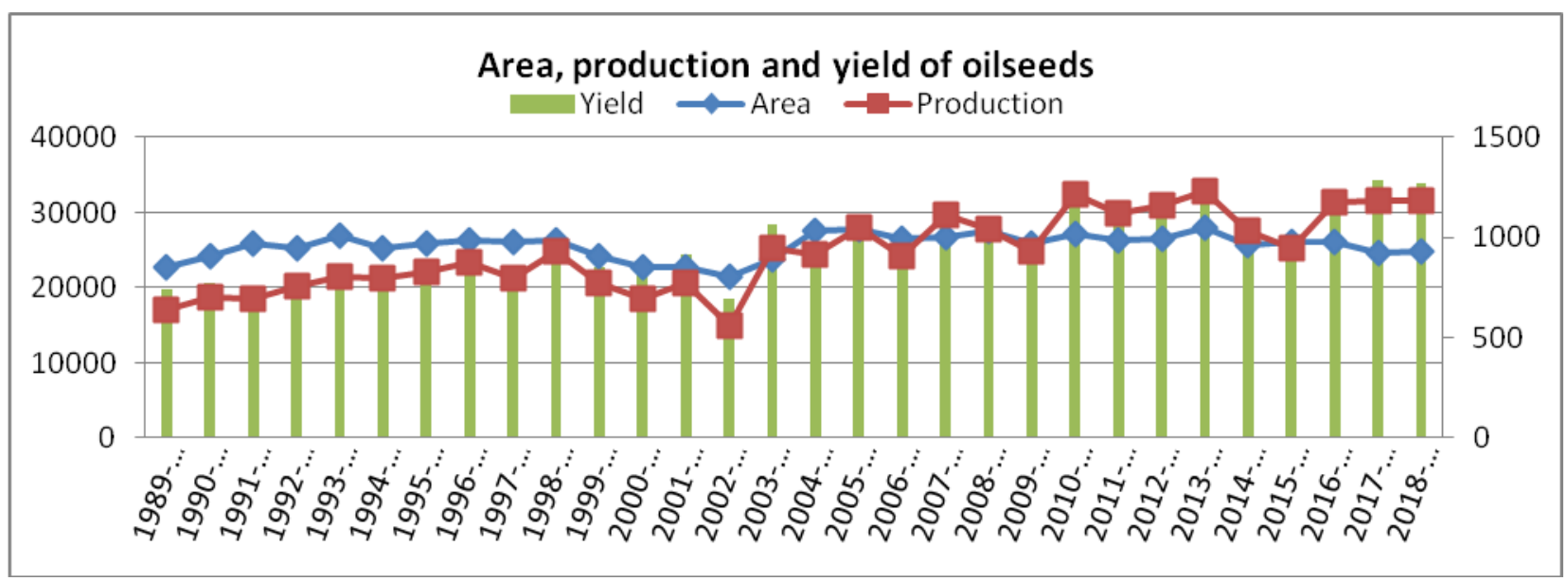

Figure 1: Area, productions and productivity of oilseeds (1989-90 to 2018-19)

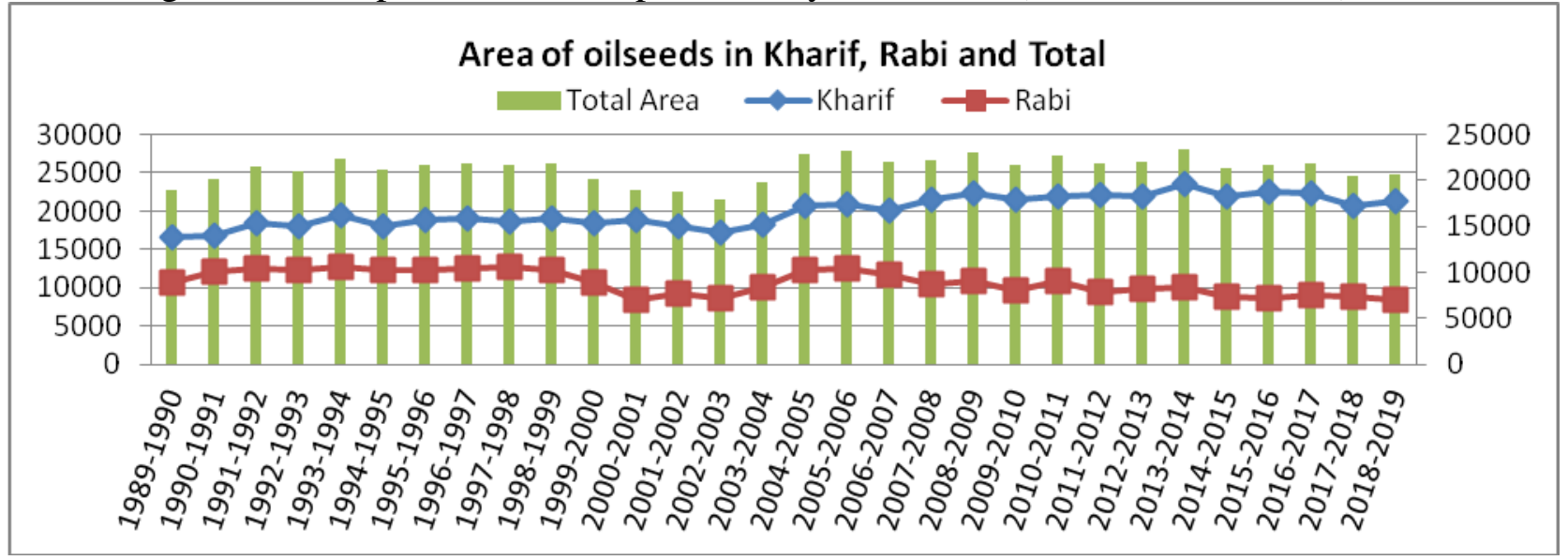

Figure 2 Season wise area under oilseed crops in India (1989-90 to 2018-19) 


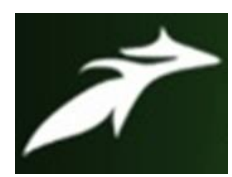

Jainuddin S. M et al, International Journal of Advances in Agricultural Science and Technology,

Vol.8 Issue.1, January-2021, pg. 1-12

ISSN: 2348-1358

Impact Factor: 6.057

NAAS Rating: 3.77

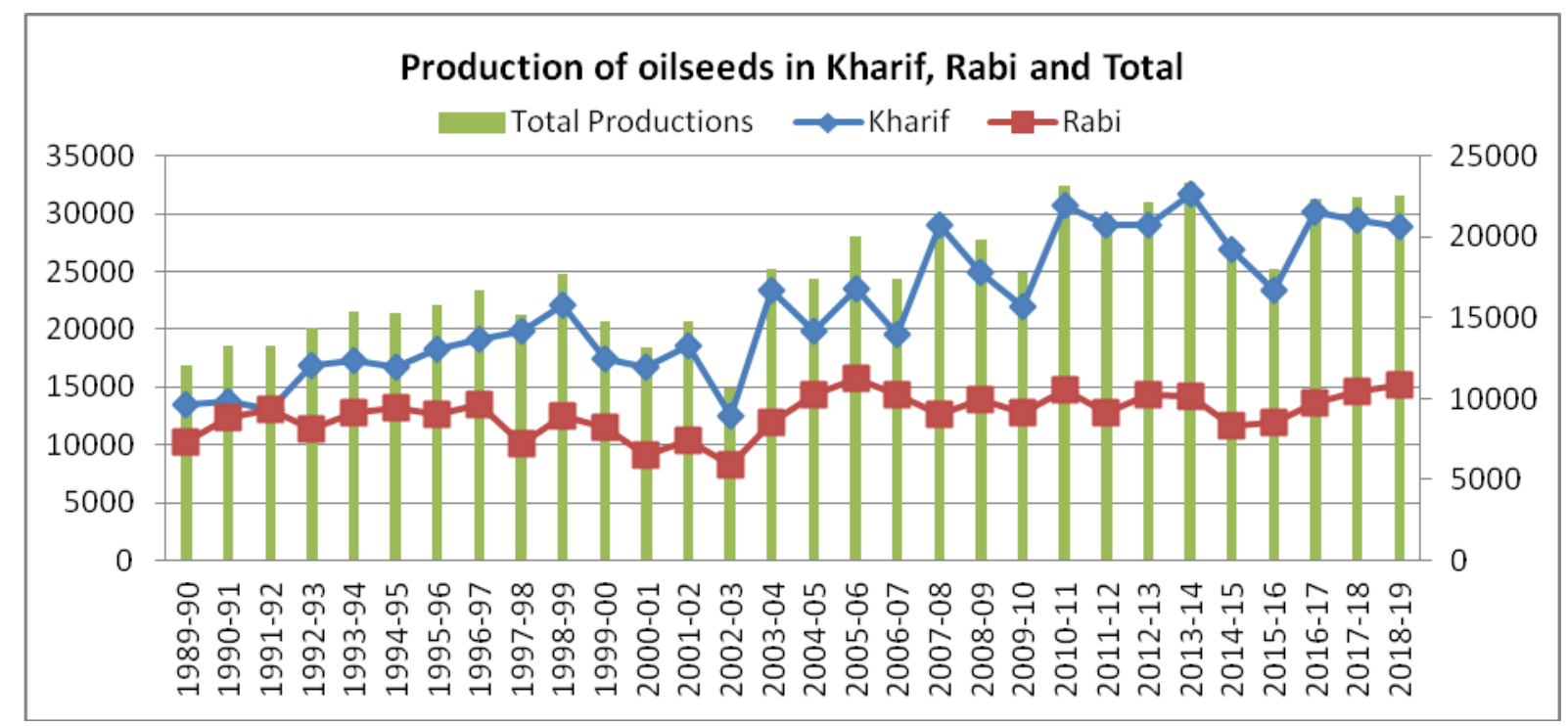

Figure 3 Season wise production of oilseeds in India (1989-90 to 2018-19)

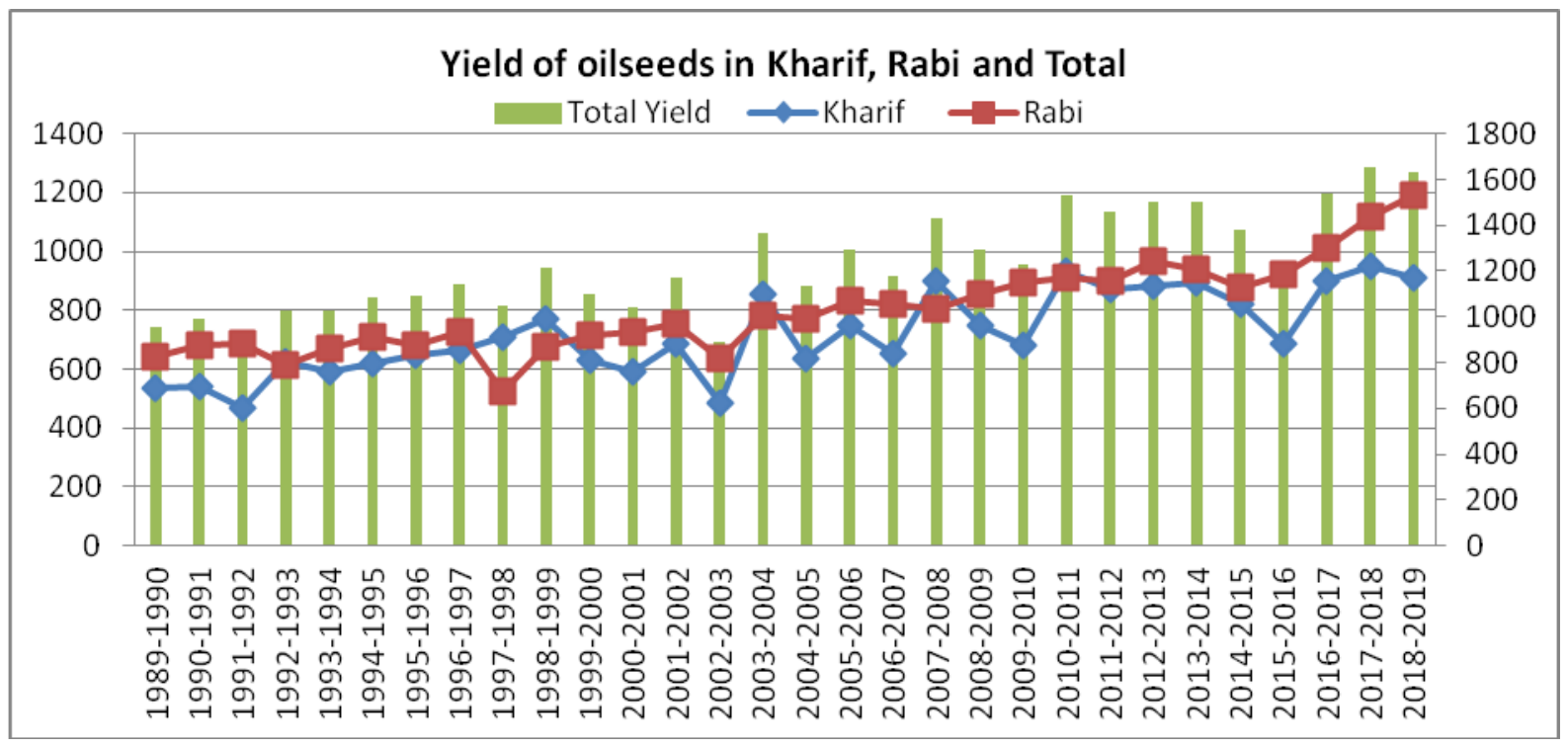

Figure 4 Season wise yield of oilseeds in India (1989-90 to 2018-19) 


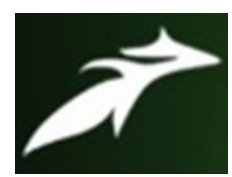

Jainuddin S. M et al, International Journal of Advances in Agricultural Science and Technology, Vol.8 Issue.1, January-2021, pg. 1-12

ISSN: 2348-1358

Impact Factor: 6.057

NAAS Rating: 3.77

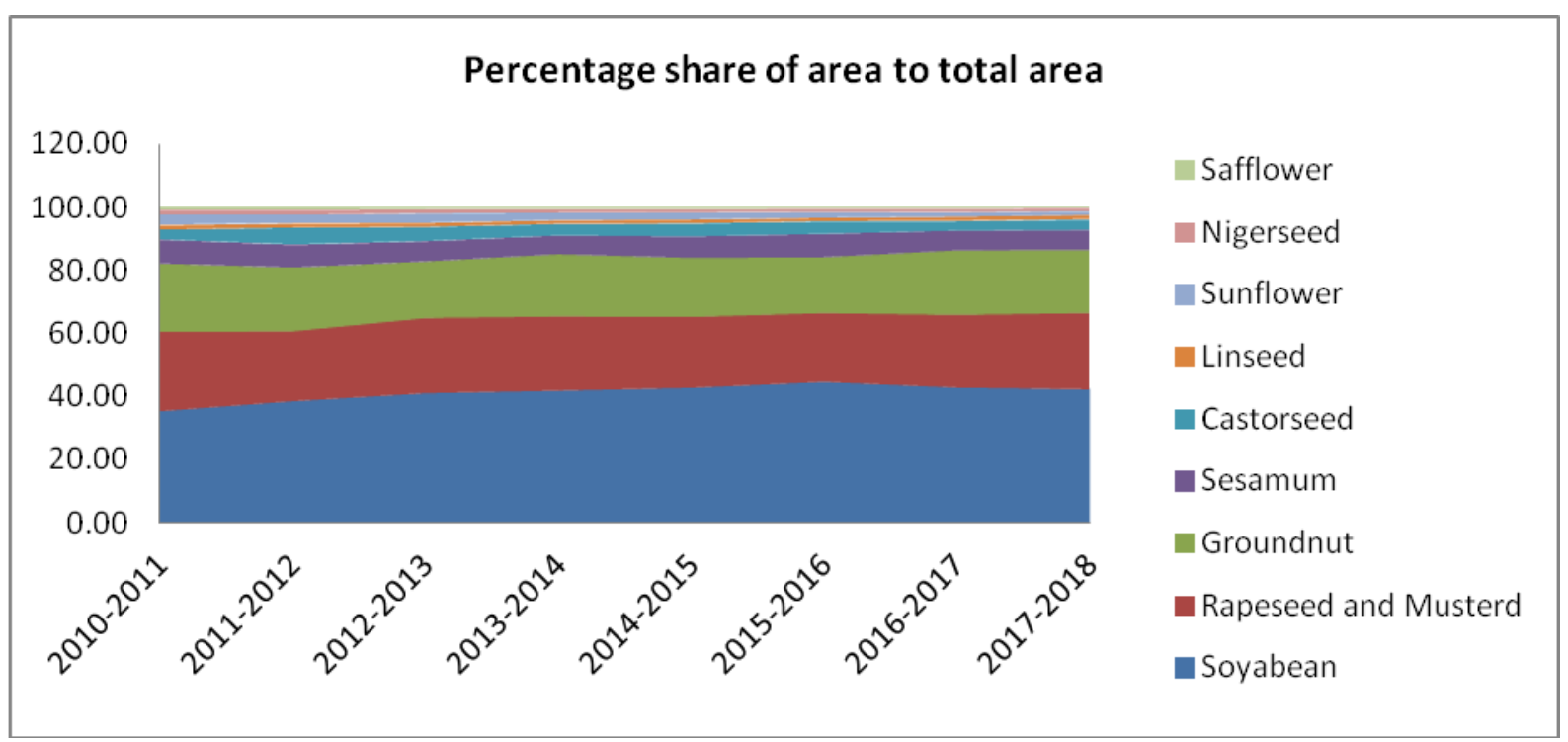

Figure 5 Percentage share of nine oilseed area to total area of oilseeds in India

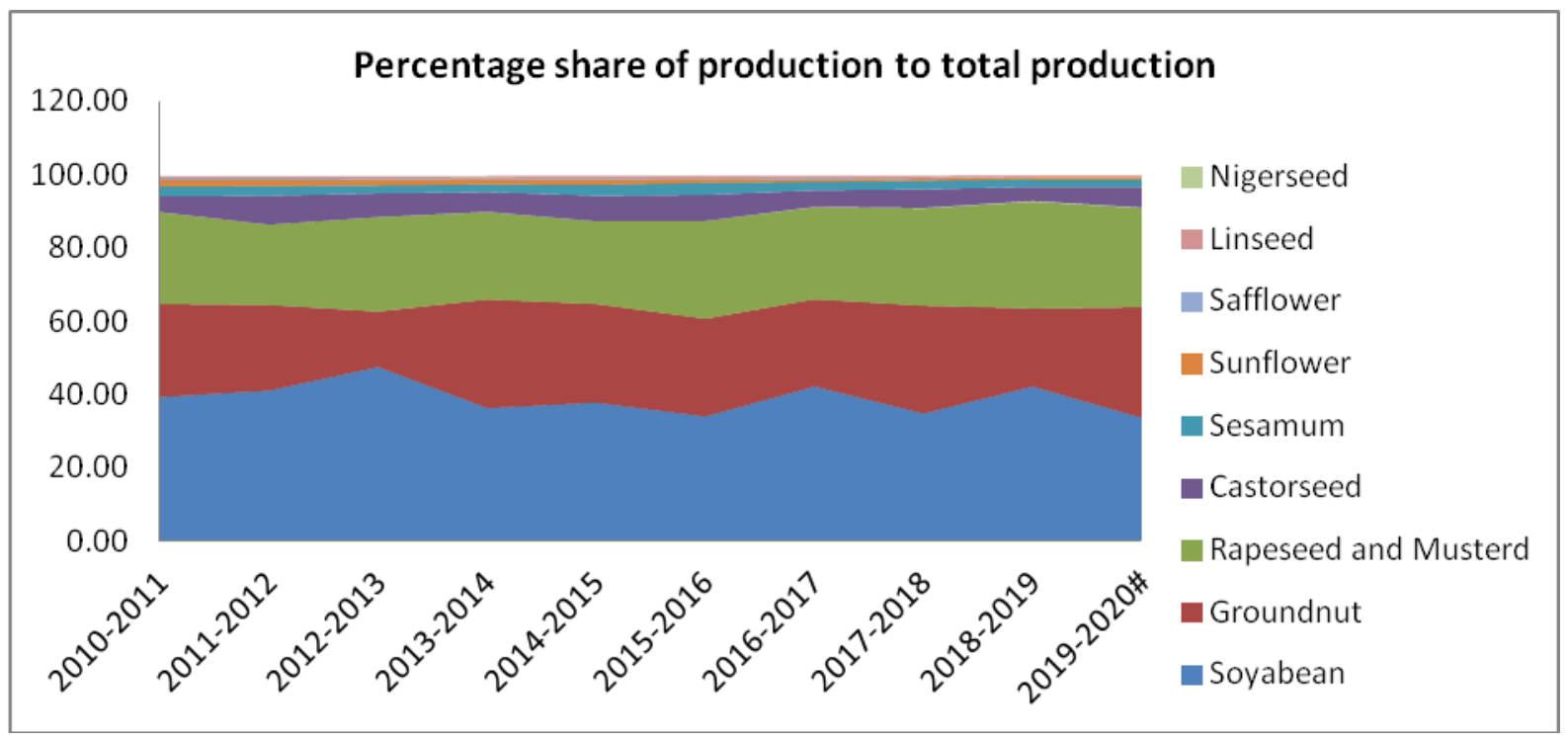

Figure 6 Percentage share of nine oilseed production to total productions in India 


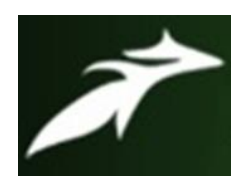

Jainuddin S. M et al, International Journal of Advances in Agricultural Science and Technology,

Vol.8 Issue.1, January-2021, pg. 1-12

ISSN: 2348-1358

Impact Factor: 6.057

NAAS Rating: 3.77

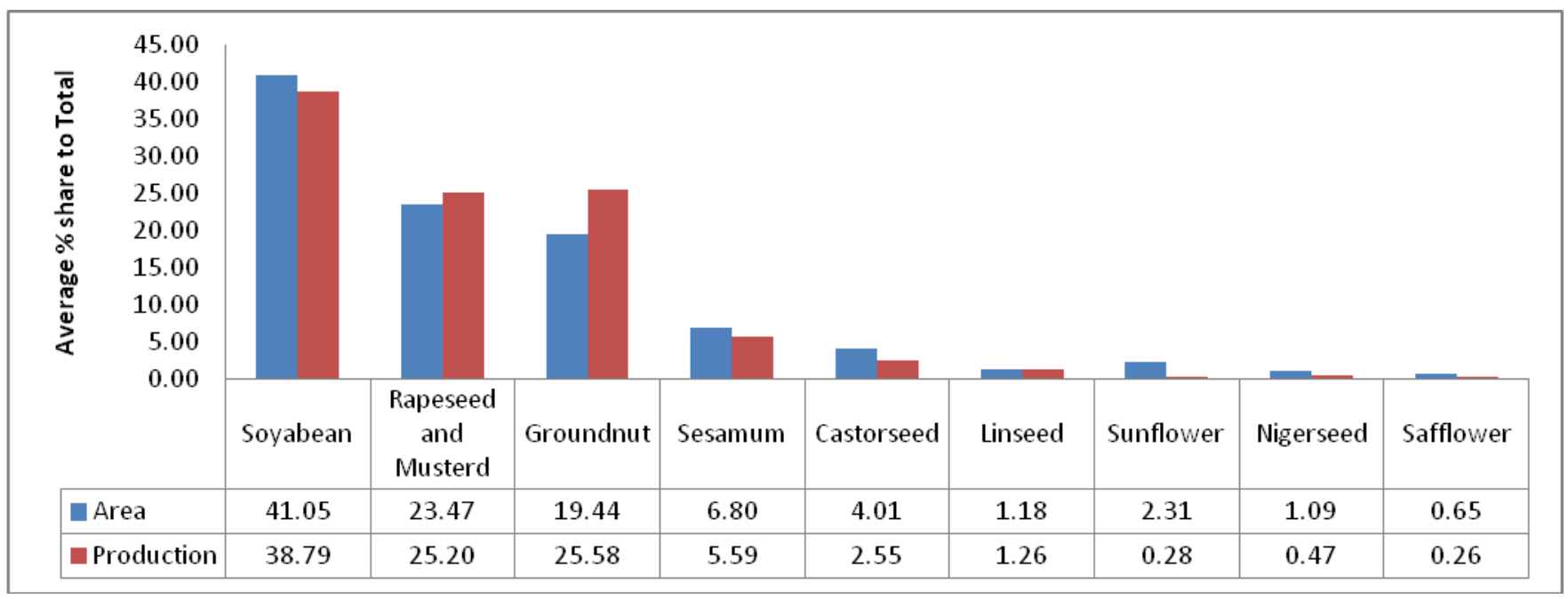

Figure 7 Average percentage shares of nine oilseeds area and production to total in India 